\title{
Spatial and environmental preconditions for the establishment of nautical tourism ports
}

\author{
M, Kovačić ${ }^{1}$, S. Favro ${ }^{2} \&$ M. Perišić ${ }^{3}$ \\ ${ }^{1}$ Faculty of Maritime Studies, University of Rijeka, Croatia \\ ${ }^{2}$ Adriatic Expert, Split, Croatia \\ ${ }^{3}$ Plovput, d.o.o. Split, Croatia
}

\begin{abstract}
This paper analyses the spatial and environmental characteristics of the Croatian Adriatic from the aspect of nautical tourism development. Analysis of the characteristics important for nautical tourism development will deal with the most attractive locations on the Croatian Adriatic, and it will recommend and suggest further development of all the elements of nautical tourism together with its complementary activities - nautical economy.

The trends observed in nautical tourism in the more developed Mediterranean tourist countries may be expected or are already present in Croatia as well. That experience facilitates the design of the development direction for Croatia. Namely, geographical, historical and the surrounding specific features of the Croatian coast, the mentality of the local inhabitants, the level of economic development which includes the development of communal, traffic and social infrastructure, etc., imposes to the planners certain limitations which were not present in those countries, or were not of the same shape and extent.

The authors analyse spatial possibilities in the function of nautical tourism development. They analyse legal features and suggest solutions that support development of nautical tourism that respects the area and its acceptance and other possibilities.
\end{abstract}

Keywords: nautical tourism port, development, special planning, environmental precondition, protection. 


\section{Introduction}

Among Mediterranean countries, Croatia has all the conditions for the development of nautical tourism and has comparative advantages in relation to the majority of other countries, which refers to better indebtedness of the coast and islands, a greater number of well positioned and sheltered ports, more favourable positioning in relation to emitting the nautical tourism market, better preserved nature and cleaner seas.

The variety of relief forms, bays, island and islets, is one of the most attractive elements of nautical tourism navigation. The indented coast offers interesting cruising and has good shelters. The Adriatic Sea is a deeply drawn bay of the Mediterranean Sea, stretching in the direction northwest-southeast. The coastline of the Croatian Adriatic is 6,278 km long, of which 1,880 km refers to the coast, and 4,398 $\mathrm{km}$ to the islands. The indentedness coefficient of 11.10 places Croatia in the second position, after Greece

\section{Defining the issue}

Even though the Croatian littoral area represents one integral whole, there are several regions with specific geological, morphological, climatic, and social characteristics that are part of larger functional macro regions. They are [8]:

- $\quad$ Northern Croatian Littoral;

- Central Adriatic;

- $\quad$ Southern Croatian Littoral.

Istria and Kvarnerski Zaljev Bay are at the utmost northern part of the Croatian coast that is deeply drawn in the European land mass. Therefore, that area has the best connections with the European countries where the tourists come from. That connection is established mainly through sea ports in Pula and Rijeka, airports in Pula and on Krk island, and through a road network that is, because of being close to the Austrian and Italian borders, easily connected to European networks. Učka tunnel and road modernization (the so called, "Istrian Y”) make this region even closer to the tourist market and even more promising in tourism development. There are two sub regions with specific geographical characteristics in this area:

- Istria, which extends from Piranski zaljev Bay to Kamenjak Cape;

- Kvarner which includes the eastern Istrian coast, Opatija Riviera and Rijeka coastal area, Vinodol and Crikvenica Riviera, foothills of Velebit, and islands in Kvarnerski Zaljev Bay (Cres, Lošinj, Krk, Rab, and smaller islands).

According to the research, $45 \%$ of the total water surface that nautical ports cover belongs to the Northern Croatian Littoral, 39\% to the Central Adriatic, and the remaining 39\% to the Southern Croatian Littoral. Intensive development of nautical tourism has caused a noticeable pressure on the environment. However, there are no data on how much funds have been invested in that period on the 
protection of the environment endangered by nautical tourism and on the safety of vessels because values have been ignored.

\subsection{Statistical data of previous development}

The beginnings of nautical tourism on the Croatian coast date between the two World Wars when boaters were using the services of the existing ports on land and on the islands. It was only late in the 1960s and early in the 1970s that the plans for building ports exclusively for nautical tourism occurred. The first period of construction of marinas lasted from 1975 to 1984, and in that period 19 marinas with 4,466 sea berths were built on the Croatian coast of the Adriatic. Individual developmental initiatives on a small number of locations were characteristic for that period, while the system of the nautical tourist offer still did not exist. The second period of construction of marinas was marked by planned development, due to the establishment of the "Adriatic Club Yugoslavia” in 1983, later renamed ACI [1]. Consequently, 20 more marinas with 5,814 sea berths were built between 1984 and 1990, so there were 39 marinas with 10,280 sea berths up to the 1990s. The interval from 1993 up to this day is marked by the privatization of marinas and the developmental interests of their new owners.

In 2008, the total number of nautical ports was 97, out of which 58 were marinas. The number of nautical ports increased for 31\% from 2002-2008, which shows a fast development of Croatian nautical tourism. According to the statistical data of the Croatian Bureau of Statistics [4] from 2009 there were 98 ports of nautical tourism on the Croatian coast. As much as 58 of them are marinas. In those 58 marinas (out of which 10 are land/dry berth) there are 21,491 berths at disposal to boaters on a water surface area of $3.293,558 \mathrm{~m}^{2}$. Apart from ports of nautical tourism, there are also more than 800 ports, little ports, and bays evenly distributed along the land and island coastline.

In one year, i.e. in 2010, the number of ports of nautical tourism increased by 2 marinas (there were 60 marinas out of which 10 were land/dry berths) and there were 65 berths $(16,913$ berths recorded in 2010) at disposal to boaters on a water surface area of $3.313,110 \mathrm{~m}^{2}$ [4].

In the Croatian tourist industry, nautical tourism makes only about $8 \%$ of the total number of arrivals or $2 \%$ of the total number of overnights. Nevertheless, it has a more dynamic growth rate than stationary tourism. One of the reasons for that is the Croatian favourable geographical position in relation to European countries where nautical tourists come from. Most nautical tourists come to Croatia from Western Europe. Therefore, German, Austrian, and Italian boaters account for $70 \%$ to $80 \%$ of the nautical business in Croatia, while domestic and Slovenian boaters account for $10 \%$ to $12 \%$.

The final analysis of nautical tourism in the Republic of Croatia has been carried out, according to statistical data of the Croatian Bureau of Statistics, from 2011. In 2011, the statistical survey covered 98 nautical ports on the Croatian coast, as follows: 61 marinas (of which 11 were land marinas) and 37 other nautical ports. The total water surface area was $3.295 .891 \mathrm{~m}^{2}$ and there were 17,059 moorings. On $31^{\text {st }}$ December 2011, there were 14,286 vessels 
permanently moored in nautical ports, which was $1.0 \%$ less than on $31^{\text {st }}$ December 2010. Out of the total number of stationed vessels, $85.5 \%$ used water moorings, while $14.5 \%$ used land moorings. The profit from nautical tourism grows every year in the whole area of the Republic of Croatia. From 2004 to 2010 the profit increased by $257.272 \mathrm{kn}$. In 2009, the profit from tourism was 6.5 billion Euros while the profit from nautical ports was approximately 75 million Euros (out of which 405, 6 million kuna was achieved from berth renting). The total profit of nautical tourism in 2009 was approximately 700 million kunas which was more than $10 \%$ of the total Croatian income from tourism. The profit from nautical ports, cruising and charters was also included in that total profit. According to data of the Croatian Bureau of Statistics, the total income realised in 98 nautical ports in 2011 amounted to 600.2 million Kuna, out of which 439.4 million Kuna (73.2\%) was realised through the renting of moorings. Compared to 2010, the total profit increased by $4.5 \%$, while the income gained through renting of moorings increased by $0.8 \%$.

Among Adriatic counties the highest income received from nautical ports (almost 140 million kunas) was by the County of Šibenik-Knin. Primorskogoranska County had an income of 94,85 million kunas or $8.5 \%$ higher in relation to 2010.

\section{Research methodology}

The following section of this study gives an overview of the main spatial and environmental features of individual counties and of legal regulations important for the establishment of the nautical tourism system in Croatia.

\subsection{Spatial plans as a factor of sustainable development of nautical tourism}

Spatial planning is a precondition for achieving a better distribution of economic functions in space, protection and enhancement of natural and man-created values, and an optimal distribution of facilities intended for some activities, including nautical tourism [20].

The scientific approach to spatial planning in nautical tourism is necessary because it is an economic activity that requires coastal and marine space as an important precondition for business and development. Of all nautical ports, marinas require a lot of top quality coastal area so the planning of their location in the space has a special significance. What attract boater's attention the most are landscape and historic urban cores, so the biggest trend in the construction of marinas is in those areas. This represents a constant threat to disrupt or even completely devaluate such areas. Experts in different fields are included in solving these issues. Available natural resources are analytically and quality viewed through the analysis of specificity in content and economy in investments. The analysis that has been carried out for the purpose of this study has indicated the need to consider new locations for nautical infrastructure, and revision of previously planned locations. From the standpoint of environmental 
protection, tourist demand for nautical and tourist capacities in an area have to be satisfied, and at the same time protect and preserve the area.

Based on the Spatial Plan of Republic of Croatia made in 1989, and the strategy of spatial planning, pursuant to the Spatial Planning Act [19] the criteria about exploiting the space were defined:

- $\quad$ capacity of nautical centres for commercial berths shall be limited to a maximum 1,000 berths, and a minimum 200 berths,

- determining the number of berths of nautical ports through the purpose of the aquatorium, while ports of nautical tourism with less than 100 berths will be considered as ports in international exclusive nautical centres in which boaters require excellent quality services.

In plans for the development of nautical ports in some counties (Primorskogoranska County, Istria County, and later other counties) in Croatia, restrictions regarding marinas' capacities for commercial berths have been established. A maximum of 1,000 berths and a minimum of 200 berths have been determined. The limitations were not determined for communal berths and sports associations, or sports boat harbours. For certain tourist accommodation capacities smaller landing places with up to 100 berths should be determined (hotel boat harbours), which will not be considered as nautical centres. Future capacities of nautical ports weren't specifically considered then by the County's master plan. The Spatial Planning Act [19] determines, for physical plans at all levels, the obligation to define the organisation, protection, exploitation and purpose of the space, respecting social and economic, natural, cultural and historical and countryside values, and other elements important for the development and protection of the environment included in the plan. Modification and amendments made to this Act in July 2004 have special importance for the protection and planning of coastal sea area. Aimed at the protection of coastal sea and purposeful, sustainable and economically efficient exploitation, this document defines the protected coastal areas (ZOP) which includes all islands, $1,000 \mathrm{~m}$ of coastal belt and $300 \mathrm{~m}$ of sea belt. The amended document determines that the Physical Planning Act is of special importance for the Republic of Croatia and that all plans within the area shall be brought upon the obtained approval of the Ministry of Environmental Protection, Spatial Planning and Construction. Pursuant to the stated Act and Amendments, construction shall not be permitted if the urban plan has not been accepted, except for the infrastructure objects beyond the construction areas.

A Decree about the management and protection of the protected coastal sea [18], determines that:

"no construction can be planned in ZOP, including single and several buildings for anchoring, if the location of anchorage has not been published in the official navigational publications.”

According to this Decree, an anchorage is a specially marked water area possibly equipped with adequate equipment for safe anchoring of vessels. In the protected coastal area (ZOP) out of the construction area it is not allowed to plan nautical tourism ports nor plan or perform the levelling of the coast. The number 
of berth places in one or more berths in a tourist unit cannot exceed $20 \%$ of the total accommodation capacity of the unit, but not above 400 berth places. According to this Decree a berth in a nautical tourism port is a place for a vessel of standard length of $12 \mathrm{~m}$, and a vessel equals 3-bed accommodation capacity. It should be noted that the number of berths in a marina is dimensioned according to a $12 \mathrm{~m}$ long yacht, which length is taken as a measurement standard berth for planning and making projects of berths in a marina. The number of berths of an existing nautical tourism port cannot be increased if such increase has not been planned by the county physical plan. The nautical tourism port is planned to be built in villages and detached construction areas for catering and tourist purposes with a maximum of 400 berth places. Various facilities may be planned in nautical tourism ports, like catering, trade, services and sports facilities. Due to a mandatory adjustment of spatial planning of coastal counties with this Regulation, counties' plans regarding nautical ports have been changed and coordinated.

The adopted Physical Planning and Construction Act [14], later referred to as the Act, Article 51 defines restrictions of interventions in the protected coastal sea (ZOP):

(1) no construction can be planned in ZOP, including issuing a location permit or a decision regarding construction conditions for construction purposes for:

- Berths and nautical ports, and levelling the coast or the sea out of the construction area,

- anchoring, if the location of anchorage has not been published in the official navigational publications.

In Article 52 of the Act it is defined "Planning of catering, tourism and sport purposes" for:

- The number of berth places in one or more berths in a tourist unit cannot exceed $20 \%$ of the total accommodation capacity.

The nautical tourism port in the construction area of village and detached construction areas outside villages can be expanded by the spatial plan of a county and new ones can be planned with the water surface of 10 ha maximum. Various facilities may be planned in nautical tourism ports, like catering, trade, services and sports and recreational facilities. Furthermore, in Article 71 of the Act, in the part that defines the content of county spatial plan it is specified:

(1) County spatial plan particularly defines:

- $\quad$ acceptable usage of areas for recreation,

(3) Areas for other purposes outside villages are also defined in the County spatial plan (location, type, the biggest capacity and type) as well as guidelines for determining detached construction areas, and purpose for:

- $\quad$ nautical tourism ports,

- $\quad$ sport purposes,

- $\quad$ areas for aquaculture and fisheries infrastructure.”

It is well known that marinas, in general, are constructed in direct contact with areas of significant tourist accommodation and recreational capacities, or 
within the harbour basins near large urban centres [8]. Marina also must have a possibility to expand in the immediate surrounding area, but not at the expense of beaches and other maritime and recreational facilities, or protected parts of nature. To determine the spatial coverage of some nautical ports, in order to determine a uniform standard, the term "berth for vessels" should be defined. A berth in a nautical tourism port is a place for a vessel of standard length of $12 \mathrm{~m}$, and a vessel equals one accommodation capacity of apartment type, or a 3-bed accommodation capacity.

It requires an area of $112.5 \mathrm{~m}^{2}$ for berths in the sea, and $90.0 \mathrm{~m}^{2}$ for dry/land berths, or the total area per berth of $101.2 \mathrm{~m}^{2}$ (land and water surface). Consequently, the water surface for a nautical port for 400 vessels should be at least $45,000 \mathrm{~m}^{2}$, i.e. 4.5 ha, not including the piers' area and other constructions in the sea. The number of yachts per hectare of aquatorium should not be under 50 or over 120 yachts. To accept the same number of vessels on the land (dry berth), an area of $36000 \mathrm{~m}^{2}$, i.e. $3.6 \mathrm{ha}$, is needed.

For Croatian conditions, it is recommended that $2 / 3$ of berths are situated in the sea, and that for $1 / 3$ of the vessels are provided places on the land. The support to such statement is, above all, the advantages of dry berths:

- conservation of natural advantages;

- rational use of available surfaces;

- greater security of vessels;

- a continuous availability to vessels;

- lower price of equipment and accommodation of vessels;

- use of the coast and water surface for more appropriate purposes.

The issue of determining a minimum capacity of marinas is significant because the minimum capacity defines the border of which an efficient use of communal, technical and sanitary facilities and equipment depend. On the other hand, an optimum capacity indicates a limit which should not be exceeded because of economic, functional and ecological reasons. The number of objects in nautical ports and their capacity reflects an optimal functionality level conditions in which the local infrastructure is able to meet the needs. Selective forms of tourism, such as nautical tourism, are the most acceptable forms of tourism due to their compatibility with natural features and possibilities that contribute to the optimal use of touristic features of the market.

\subsection{Spatial and environmental features}

According to expert opinion, Croatian nautical tourism is at its turning point. In order to attain high efficiency and a continuous and balanced development, the strategy, partial managing of subjects and objects of nautical tourism has to be harmonised with specific features and requirements of the local community for the purpose of sustainable development. The Croatian Government decided to order a study of the development of the nautical tourism of Croatia from a scientific experts' team headed by the Hydrographic Institute of the Republic of Croatia [16]. 
The vision of nautical tourism in the Republic of Croatia is to be the regional leader in nautical tourism and act so through optimal exploitation of the complete capacities and comparative advantages, trying to establish the balance between the overall atmosphere of the stay and maximum protection of the environment.

The mission of the system of nautical tourism is to ensure the quality service to each boater in order to satisfy all their needs in accordance with the policy of preserving the physical and landscape values of the coast, for the purpose of social and economic prosperity of the locations and areas where the activity is performed.

When selecting the location, the most important criteria should be a protected position and physical and ecological acceptability (multi-criteria analysis of the location's natural characteristics). Before planning the construction it is necessary to conduct comprehensive hydrologic, oceanographic and meteorological research and specify the possible negative consequences for the living world of the area.

Obtained data would determine the potential of a particular area for development of nautical tourism capacities considering geographical, maritime, ecological, social and economic characteristics of the location [13]. Wide presentation of obtained data to local communities, holders of preliminary initiative for development of particular nautical structure (marina, port) would be accompanied by the acceptance of general government's orientation as a holder of nautical tourism development.

The development of nautical tourism in Croatia has to provide quality services to each boater in order to satisfy all their needs in accordance with the policy of preserving the physical and landscape values of the coast, for the purpose of social and economic prosperity of the locations and areas where the activity is performed.

Conclusions of the study of the development of nautical tourism in Croatia predict the development of about 15,000 berths in the next 10 years by the development of new marinas, dry marinas and coastal and insular nautical ports and moorings.

\subsection{Selecting the location of nautical destination: acceptance capacity of the location}

Further development of reception capacities of nautical tourism (marinas, nautical ports and dry marinas) should be connected with the existing tourist destinations on the coast that already have infrastructure and partly disrupted environment [10]. When choosing locations for the development of new marinas, priority should be given to the areas that are already devastated, such as abandoned industrial and military structures. In the existing marinas, it is necessary to carry out a qualitative restructure of the capacities together with the advancement of the quality of services, in order to make the marinas qualified to satisfy the needs of a modern boater. In the analysis of the existing offer of nautical capacities, areas for marinas near airports and important traffic routes 
should be defined, especially in the south of the Croatian coast with the world famous tourist destination - Dubrovnik that lacks in receptive nautical capacities.

An important role in sustainable development of nautical tourism in Croatia should have the existing town and tourist ports on islands [7]. Their modernization contributes to that area's humanization, and in this way they can be included in the nautical supply of Croatia. Those ports are very picturesque by themselves, because they fully reflect the identity of Istria, Kvarner, and Dalmatian coastal towns that - besides being natural - also have tourist attractiveness. It is necessary to provide safe berths, electricity and water supply, toilets and waste disposal. Boaters don't usually stay too long in these ports; only for the purpose of supplying or in the case of bad weather. Tourist towns are an important element of tourist supply, therefore revitalization and modernization of their ports is very important, as well as their adaptation to meet the standards of modern nautical demand.

In strategic development, it is essential to determine specific infrastructural and logistic requirements of marinas as well as the needs and expectations of their guests [9]. When choosing a location for the construction of a marina it is important to choose the ones that are less attractive for other forms of selective tourism, and the one that meet the needs of constructing a marina or port for boaters. One of the key factors in decision making regarding the construction or expansion of marinas and ports, as well as other nearby facilities, is the preservation of the environment and its maximum protection. The development has to be within the limits of the sustainability of capacities [12, 17]. The trends on the Mediterranean that indicate an increase in the length of vessels should be taken into account as well as the growing demand for nautical destinations. According to many authors [2, 3], the socio-economic effects of marinas are reflected in recovering locations and they stimulate the development of the environment.

\section{Results and recommendations}

In analysing existing trends of development of the nautical economy and nautical tourism with complementary activities on the Mediterranean, it is visible that the Northern Adriatic has to develop models of adjustments and implementation of successful trends from the surrounding area.

In fact, the vicinity and accessibility of the Northern Adriatic as a comparative advantage has dropped to second place in comparison with the nautical and more attractive Dalmatian sea due to the development of transport connections of the Central Adriatic and Southern Croatian Littoral with leading European markets (highway; low cost airlines).

The result was a drop in demand for an annual berth, as well as reduced transit in this area. Monitoring leading nautical destinations of the Mediterranean that have substituted their lack of natural attractiveness of the sea intended for cruising with specially developed complementary activities and with connections with other selective forms of tourism, the need to adapt and implement the existing models to revive the nautical tourism traffic is obvious. A possibility for 
a better presentation of local, cultural, artistic, gastronomic, sport and entertainment offer through organisation of thematic cruising (individual, fleet, racing) raises by making interconnections of all entities of nautical tourism with the county and local tourist boards. With better organisation of communal moorings and anchorages, and their interaction with major nautical and economic entities, marinas will provide a synergic economic effect on the entire area, and, which is more important, it will raise the general attractiveness of the sea in the Primorsko-goranska County. An appropriate and attractive service will be provided by such an approach in order to prolong the stay of vessels on permanent berth in County marinas before sailing towards Dalmatian waters during seasonal summer cruises. It will boost sailors' arrivals on weekend sailing trips during the early and late season.

Attractive facilities and interesting events can provide an appropriate relaxing entertainment atmosphere to weekend boaters, sometimes even without the need to sail from the main marina if the feeling that the owner of the vessel feels at home is achieved. This can be achieved by encouraging the development of indigenous activities and catering services during the season on the harbour shore - the waterfront. In this way, the attractiveness of a certain locality in touristic offer would be raised, and until now, little known coastal and island places would become even more attractive in the field of nautical tourism.

Special attention should be paid to the organisation of moorings for mega yachts with all necessary infrastructural demands, as well as the type and level of services that this type of clientele seeks. Construction of berths for mega yachts (3-5) should be envisaged for all coastal and island marinas that would have the potential to attract the wealthiest segment of the market in nautical demand, that has been in a constant exponential rise on the Mediterranean in the last decade by presenting its attractiveness in an appropriate professional way (Croatian Tourist Board).

Based on conclusions from the Study, the most attractive locations for receiving the exclusive type of boaters on their own or chartered vessels - mega yachts have been recognized. On those locations it is necessary to ensure berths meet the needs for infrastructure, an excellent offer of products and services, and ensure high quality accommodation on the coast if needed. For the best clients of this type of tourism, the excellent tourist offer should be ensured [15].

Despite the financial crisis, seen from the aspect of the production of mega yachts, that segment still shows growth, while in the maritime business, demand still exceeds supply. Benchmark analyses that have been carried out have shown that successful mega yacht marinas are mainly focused on the quality of basic service delivery (anchoring, food and drink delivery, technical services, etc.) and their personalisation and not on the choice of comfort. However, it has been proven that the combination of doing business between the marina and real estates and commercial tourism (hotel, wellness, shopping) is almost mandatory. Today, five ACI marinas located on the Northern Adriatic have been qualified for admission to accept mega yachts: Umag up to $40 \mathrm{~m}$ in length, Rovinj up to $60 \mathrm{~m}$, Pula up to $25 \mathrm{~m}$, Cres up to $50 \mathrm{~m}$ and Opatija up to $40 \mathrm{~m}$ in length. The term yacht for personal use should be defined. In Croatian practice it is defined 
as a vessel on which a simultaneous presence of more than 12 passengers is not possible and which is primarily used for leisure, sport and recreation. Nautical ports Split and Dubrovnik can accept mega yachts of up to 60 meters in length while the marina in Korčula can accept a vessel up to 40 meters in length. The number of such berths in Croatia is insufficient so owners take their mega yachts to competitive countries, such as, Monte Negro, Italy and Greece. Two locations on the Southern Adriatic (Split and Dubrovnik) are still being considered to construct or, in the existing marinas, to expand the area (water surface) to accept mega yachts. It should be emphasized that it is desirable that locations where mega marinas would be constructed are near mainland airports, and that is why these two cities have been chosen.

A special segment of nautical tourism is traditional cruising sailboats. The Croatian fleet today has about 300 boats for several days' cruising and daily excursions with food preparation. Wanting to attract clients from Western Europe that have better purchasing power, most of the ship owners repair and reconstruct their boats during the winter break in order the improve the quality of their service. In careful selection of interesting locations on the coast, it is necessary to choose ports that could, with the help of the government, be renovated to accept cruising boats. After organizing such system of ports for traditional sailboats that would be equipped with appropriate infrastructure, the system for organizing cruising and berth reservation would be established.

\section{Conclusion}

A systematic approach to further development means different organization of nautical tourist supply in order to avoid business moves that could have a devastating effect on natural surroundings. Therefore, complete developmental problems should be based on taking into consideration high ecological standards in nautical tourism and optimal consumption of Croatian natural capital. Every marina - existing or the ones that will be built - should be approached in a differentiated manner. In the development of the approach it is necessary to take into consideration other elements apart from micro location, such as: urbanization of wider marina micro location, hydro meteorological characteristics of the area where the marina is situated, and its distance from the nearest nautical corridors, etc. By taking into consideration the complexity of those and other variables, new standards in nautical tourism of the Republic of Croatia will be set that appropriately determine the mission and vision of future development.

Through the further development of Croatian nautical economy, economic and social prosperity of the regions where it is organised will be ensured. Exploiting comparative advantages, such as the Adriatic Mecca should transform the nautical tourism system into a "boaters' paradise in the middle of Europe" which will offer adventure and the feeling of safety and uniqueness. 


\section{References}

[1] Adriatic Croatia International Club, ACI Marinas.

[2] Bizzarri C., La Foresta D., Yachting and pleasure crafts in relation to local development and expansion: Marina di Stabia case study, 2nd International Conference on Physical Coastal Processes, Management and Engineering, Coastal Processes, Naples, Italy, WIT Transactions on Ecology and the Environment, Volume 149, 2011, 53-61.

[3] Cooper, W., Yachts and Yachting, Being a Treatise on Building, Sparing, Canvassing, Sailing and the general Management of Yachts. Memphis, Tennessee, USA. General Books, 2010.

[4] Croatian Bureau of Statistics of Croatia www.dzs.hr

[5] Environment Protection Act, "Official Gazette" 82/94, 128/99.

[6] Favro, S. \& Kovačić, M., Physical plans in managing sea and coastal area, $25^{\text {th }}$ International Conference on Organizational Science Development, „Change management”, pp. 1049-1058, Portorož, Slovenia, 2006.

[7] Favro, S., Kovačić, M., Gržetić, Z., Towards sustainable yachting in Croatian traditional island ports, Environmental Engineering and Management Journal, 9(6), p. 787-794, 2010.

[8] Favro, S., Kovačić, M., Nautical tourism and nautical tourism ports, Spatial features of the Croatian Adriatic, Selecting locations for nautical tourism ports, Split: Branch of Matica hrvatska, 2010.

[9] Gračan D., Strategic Thinking in Developing Nautical Tourism in Croatia, Faculty of Tourism and Hospitality Management, University of Rijeka, Croatia, Tourism and Hospitality Management, Vol. 12, No. 1, 111-117, 2006.

[10] Group of authors: New Trends Towards Mediterranean Tourism Sustainability, chapter Kovačić, M: Sustainable development of nautical tourism in Croatia, Hospitality, Tourism and Marketing Studies, Nova Science Publishers, Inc. Hauppauge NY 11788-3619, USA, 2012.

[11] Johnson, L., Clean marinas, clean boat bottoms and nontoxic antifouling strategies. http://www.icomia.com/library/introduction.asp 2005.

[12] Klarić, Z., Determining carrying capacity in the Mediterranean, and its impact on understanding sustainable tourism development In: Towards sustainable tourism development in Croatia. Proceedings International conference pp. 17-32, Zagreb: Institute for Tourism, Zagreb, 1994.

[13] Kovačić, M., Luković T., Spatial characteristics of planning and construction of nautical tourism ports, GEOADRIA, 12(2), 131-147, 2007.

[14] Law on Spatial Planning and Construction, Official Gazette 76/07, 38/09, $55 / 11,90 / 11$.

[15] Luck M., Nautical Tourism: Concepts and Issues, Cognizant Communication Corporation, New York, USA, 2007.

[16] Ministry of Sea, Traffic and Infrastructure, Ministry of Tourism, 2009-2019 Development strategy of nautical tourism in the Republic of Croatia. Zagreb: Ministry of the Sea, Transport and Infrastructure, Ministry of Tourism, 2008. 
[17] Orams, M., Marine Tourism: Development, Impacts and Management. London, UK. Routledge, 1999.

[18] Regulation on Management and Protection of Coastal Marine Areas, Official Gazette 128/04.

[19] Spatial Planning Act, Official Gazette 30/94, 68/98, 61/00, 32/02, 100/04)

[20] Šimunović, I., Planning or the Right on the Future, Marjan tisak, Split, 2005. 